\title{
Education of making and distribution of betel leaves hand sanitizers to kefamenanu Pasar Baru sellers
}

\author{
Marselina Theresia Djue Tea ${ }^{1 *}$, Matius Stefanus Batu ${ }^{1}$, Lukas Pardosi ${ }^{1}$, Welsiliana ${ }^{1}$, \\ Grandianus Seda Mada ${ }^{1}$, Dira Asri Pramita ${ }^{1}$, Desta Gloria Siahaan ${ }^{2}$ \\ ${ }^{1}$ Fakultas Pertanian, Universitas Timor, Kefamenanu, NTT, Indonesia \\ ${ }^{2}$ Fakultas Ilmu Pendidikan, Universitas Timor, Kefamenanu, NTT, Indonesia \\ *Email: marselina.yunitea@unimor.ac.id
}

\begin{abstract}
The business' level, lack of knowledge about the making process and use of hand sanitizers from natural ingredients caused sellers in Pasar Baru Kefamenanu do not apply the health protocols during transactions with buyers. Therefore, there needs to be educated about natural ingredients that can be used as hand sanitizers, the making process, and how to use them. Natural ingredients that are found in Kefamenanu are betel leaves. Education on making hand sanitizers from betel leaves helps sellers to be able to make their own hand sanitizers. The addition of aloe vera to betel leaves extract aims to make the liquid hand sanitizer becomes softer. While lime and perfume are to get rid of the betel leaves' smell. The distribution of hand sanitizers that has been made can be an example of products from natural ingredients and the storage bottles provided can be used as a refill place for hand sanitizer.
\end{abstract}

Keyword: Hand sanitizer, Betel Leaves, Aloe Vera, Lime

\begin{abstract}
Abstrak
Tingkat kesibukan yang tinggi, kurangnya pengetahuan tentang pembuatan dan penggunaan hand sanitizer dari bahan alami menyebabkan pedagang di Pasar Baru Kefamenanu tidak menerapkan protocol kesehatan selama transaksi jual beli dengan pembeli. Oleh karena itu, perlu ada edukasi tentang bahan alami yang dapat digunakan sebagai hand sanitizer, proses pembuatan, dan cara menggunakannya. Bahan alami yang banyak ditemukan di Kefamenanu adalah daun sirih. Edukasi pembuatan hand sanitizer dari daun sirih membantu pedagang untuk dapat membuat hand sanitizer sendiri. Penambahan lidah buaya pada ekstrak daun sirih untuk membuat cairan hand sanitizer menjadi lebih lembut. Sedangkan jeruk nipis dan parfum untuk menghilangkan bau daun sirih. Sedangkan pembagian hand sanitizer yang telah dibuat dapat menjadi contoh produk dari bahan alami dan botol penyimpanan yang diberikan dapat dijadikan tempat isi ulang hand sanitizer.
\end{abstract}

\section{Kata Kunci: Hand sanitizer, Daun Sirih, Lidah Buaya, Jeruk Nipis}

\section{PENDAHULUAN}

Permasalah global yang sedang dihadapi diseluruh dunia saat ini adalah penyebaran virus korona yang membunuh jutaan manusia. Adanya korona ini menuntut kita untuk menjaga kebersihan dan membatasi diri dalam pergaulan sehari-hari. Kurangnya fasilitas kesehatan yang digunakan untuk mendeteksi dan menyembuhkan penyakit korona mengharuskan kita untuk menjaga diri agar tidak terkontaminasi. Salah satu cara yang dapat digunakan adalah menjaga kebersihan tangan dengan selalu menggunakan hand sanitizer. Salah satu yang dapat digunakan adalah dari ekstrak daun sirih.

Daun sirih dalam pengobatan tradisional digunakan untuk menguatkan gigi, menyembuhkan luka-luka kecil dimulut, menghentikan pendarahan di gusi, obat kumur, dan , menghilangkan bau badan (Opilia et al., 2016). Daun sirih merupakan tanaman yang memiliki aktivitas sebagai antibakteri (Widyaningtias et al., 2014). Penelitian yang dilakukan oleh Kursia et al. (2016) menunjukan bahwa, ekstrak etilasetat daun sirih hijau mengandung senyawa antibakteri 
yang terdiri dari senyawa fenol dan turunannya memiliki aktivitas antibakteri terhadap S.epidermidis dalam kategori sedang-kuat.. Kandungan fenol (karvakrol) dan fenilpropan (eugenol dan kavikol) di dalam minyak atsiri daun sirih hijau berfungsi sebagai antiseptik (bakterisida dan fungisida yang sangat kuat) (Opilia et al., 2016). Penelitian yang dilakukan oleh Sari dan Isadiartuti, (2006) menunjukan bahwa sediaan gel yang dihasilkan berwarna kuning pucat dan hasil uji replika pada kadar ekstrak 15\%, jumlah koloni yang tumbuh setelah pemakaian berkurang sampai dengan 50\%. Sedangkan kadar $25 \%$ menunjukkan tidak adanya pertumbuhan mikroorganisme pada media. Oleh karena itu, kelangkaan hand sanitizer dan kurang mampunya masyarakat untuk membeli hand sanitizer mendorong adanya upaya untuk membuat hand sanitizer dari daun sirih.

Edukasi pembuatan hand sanitizer perlu dilakukan kepada para pedagang dikarenakan tingkat kesibukan dan kepadatan penjual dan pembeli di Pasar Baru Kefamenanu yang sangat beresiko tertular virus korona. Namun, masih rendahnya kesadaran akan bahaya virus korona menyebabkan banyak yang tidak menjaga kebersihan tangan. Oleh karena itu, hasil pembuatan hand sanitizer akan dibagikan kepada para pedagang di Pasar Baru Kefamenanu. Selain itu, para pedagang akan diberikan edukasi cara pembuatan hand sanitizer daun sirih agar dapat diproduksi sendiri di rumah.

\section{METODE PELAKSANAAN}

Pengabdian kepada masyarakat ini bertujuan untuk memberikan edukasi cara pembuatan hand sanitizer dan pembagian hand sanitizer kepada para pedagang di Pasar Baru Kefamenanu. Tahapan kegiatan yang dilakukan yaitu pembuatan hand sanitizer dari daun sirih, edukasi cara membuat, dan pembagian hand sanitizer. Alat dan bahan yang digunakan untuk membuat hand sanitizer antara lain adalah daun siri sebagai bahan aktif anti bakteri, lidah buaya sebagai bahan pelembab dan pelembut, jeruk nipis untuk menghilangkan aroma khas sirih dan parfum sebagai pewangi serta botol plastik ukuran $100 \mathrm{~mL}$ sebagai wadah untuk menyimpan campuran bahan-bahan hand sanitizer. Adapun proses membuat hand sanitizer yang dimaksud adalah sebagai berikut:

a. $50 \mathrm{~g}$ daun sirih dicuci bersih, dikeringkan, dan dipotong-potong.

b. Dimasak dengan $100 \mathrm{~mL}$ air bersih sampai mendidih.

c. Ekstraknya disaring dan didinginkan.

d. Lidah buaya secukupnya dimasak sampai matang, didinginkan, dan dihaluskan.

e. Ekstraknya di saring

f. Perasan jeruk nipis di saring

g. Campurkan ekstrak daun sirih, lidah buaya, air jeruk nipis, dan parfum secukupnya.

h. Campuran dimasukan ke dalam botol $100 \mathrm{~mL}$.

Langkah-langkah membuat hand sanitizer ini disajikan pada Gambar 2.1 


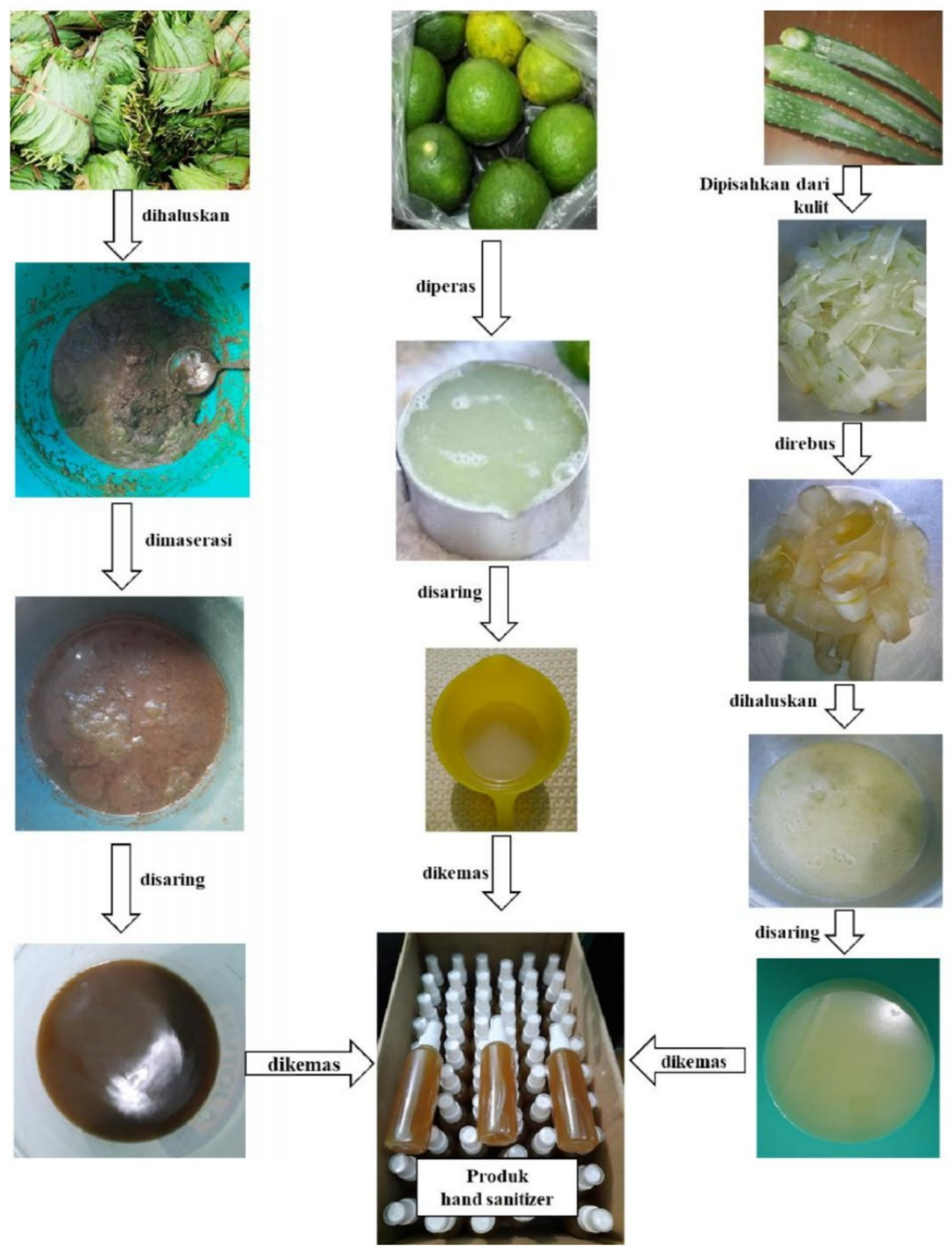

Gambar 2.1. Proses Pembuatan Hand Sanitizer Daun Sirih

\section{HASIL DAN PEMBAHASAN}

\section{a. Pembuatan Hand sanitizer}

Pembuatan hand sanitizer ini menggunakan bahan alami yaitu daun sirih hijau (Piper betle, L.), lidah buaya (Aloe vera), dan jeruk nipis (Citrus aurantifolia). Daun sirih dicuci kemudian diblender hingga halus untuk mempermudah proses penyarian zat aktif yang terkandung didalamnya. Proses penyarian atau ekstraksi dilakukan menggunakan pelarut air panas melalui metode maserasi. Hasil maserasi difiltrasi untuk memisahkan komponen padatan daun sirih dari ekstraktan. Sedangkan lidah buaya sebagai bahan tambahan pada produk dipisahkan kulit dari dagingnya kemudian direbus lalu dihaluskan. Sari lidah buaya yang telah dihaluskan masih 
mengandung padatan sehingga dilakukan filtrasi. Lidah buaya sebagai bahan tambahan produk berfungsi sebagai pelembut di tangan saat digunakan. Bahan tambahan lain seperti jeruk berfungsi untuk menghilangkan aroma sirih. Bahan-bahan hand sanitizer yang telah tersedia dicampur dengan rasio ekstrak sirih terhadap campuran lidah buaya-jeruk nipis 4:1. Sehingga volume ekstrak sirih $80 \mathrm{ml}$, sedangkan volume campuran lidah buaya-jeruk nipis yang digunakan adalah $20 \mathrm{ml}$. Konsentrasi ekstrak sirih dalam setiap kemasan botol adalah $80 \%$. Konsentrasi ini lebih tinggi dibandingkan hasil penelitian Sari dan Isadiartuti (2006) yang menyatakan bahwa aktivitas antiseptik sediaan gel hand sanitizer dengan kadar ekstrak daun sirih $15 \%$ tidak berbeda bermakna dengan sediaan etanol sedangkan sediaan dengan kadar ekstrak $20 \%$ dan $25 \%$ mempunyai aktivitas yang sama dengan sediaan triclosan. Konsentrasi ekstrak sirih yang tinggi diharapkan lebih efektif dalam membunuh bakteri pathogen. Campuran kemudian diaduk secara manual hingga homogen membentuk larutan berwarna merah kecoklatan. Sebelum di kemas dalam botol, ke dalam hand sanitizer ditambahkan parfum untuk memberikan aroma wangi pada produk tersebut. Secara keseluruhan proses pembuatannya ditunjukkan pada Gambar 3.1.

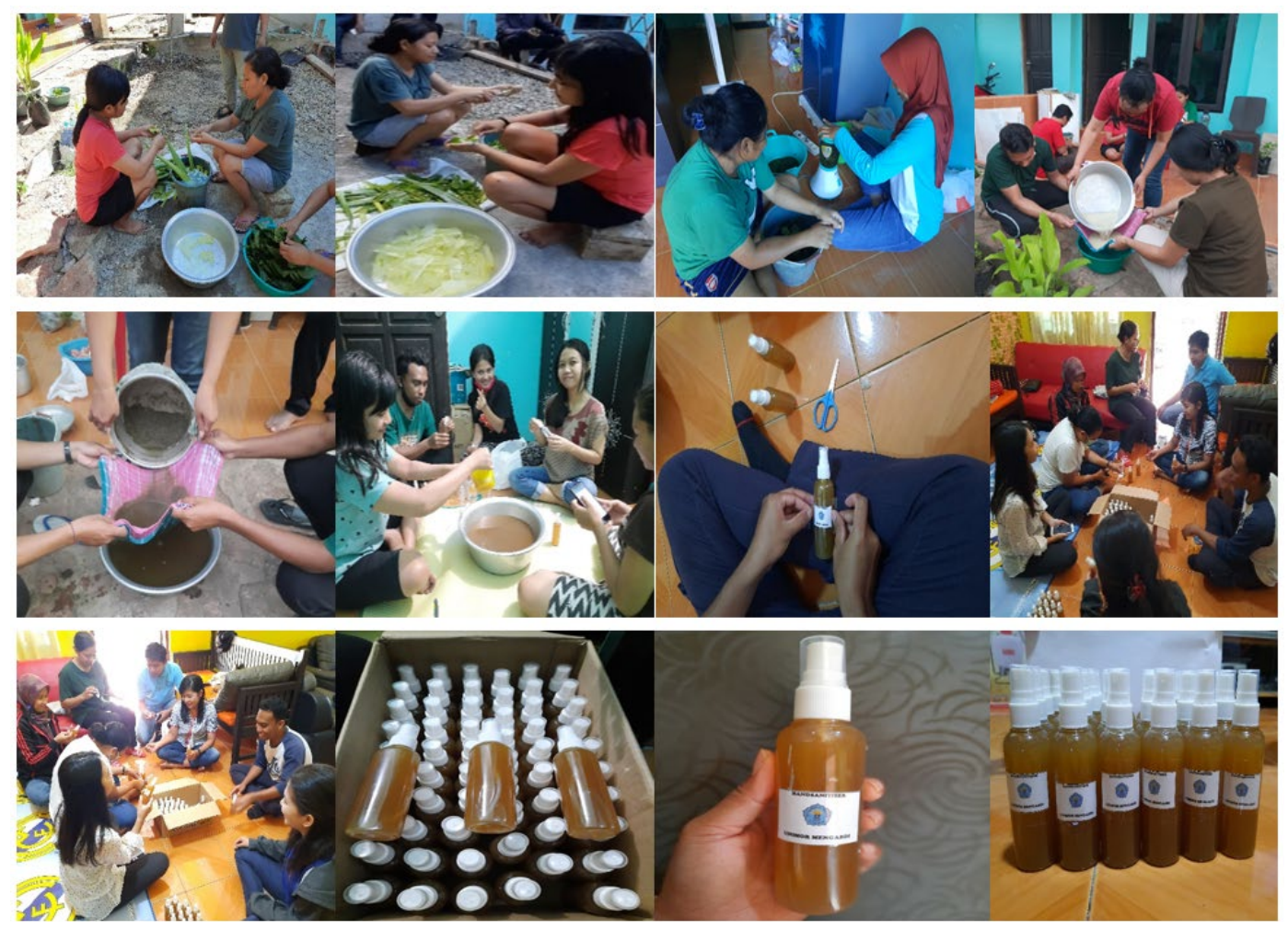

Gambar 3.1. Proses Pembuatan Hand Sanitizer Daun Sirih oleh Tim Pengabdian.

\section{b. Edukasi dan Pembagian Hand sanitizer}

Edukasi dan pembagian hand sanitizer dilaksanakan di Pasar Baru Kefamenanu, Kecamatan Kota Kefamenanu, Kabupaten Timor Tengah Utara, Provinsi Nusa Tenggara Timur. Edukasi dilakukan secara perseorangan melalui kunjungan ke lapak pedagang oleh 4 partisipan untuk menghindari kerumunan. Edukasi ini membantu pedagang untuk lebih mengetahui tentang cara menggunakan dan manfaat hand sanitizer.

Pembagian hand sanitizer tidak dilakukan secara menyeluruh kepada semua pedagang mengingat keterbatasan jumlah produk. Oleh karena itu, pembagian dilakukan secara acak dengan mempertimbangkan layak tidaknya pedagang dijadikan sebagai penerima melalui observasi langsung oleh masing-masing partisipan di lokasi kegiatan. Pembagiannya lebih 
diutamakan bagi pedagang yang kurang mampu dengan melihat jumlah dan jenis komoditas yang diperjualbelikan. Proses edukasi dan pembagian hand sanitizer terlihat pada Gambar 3.2.

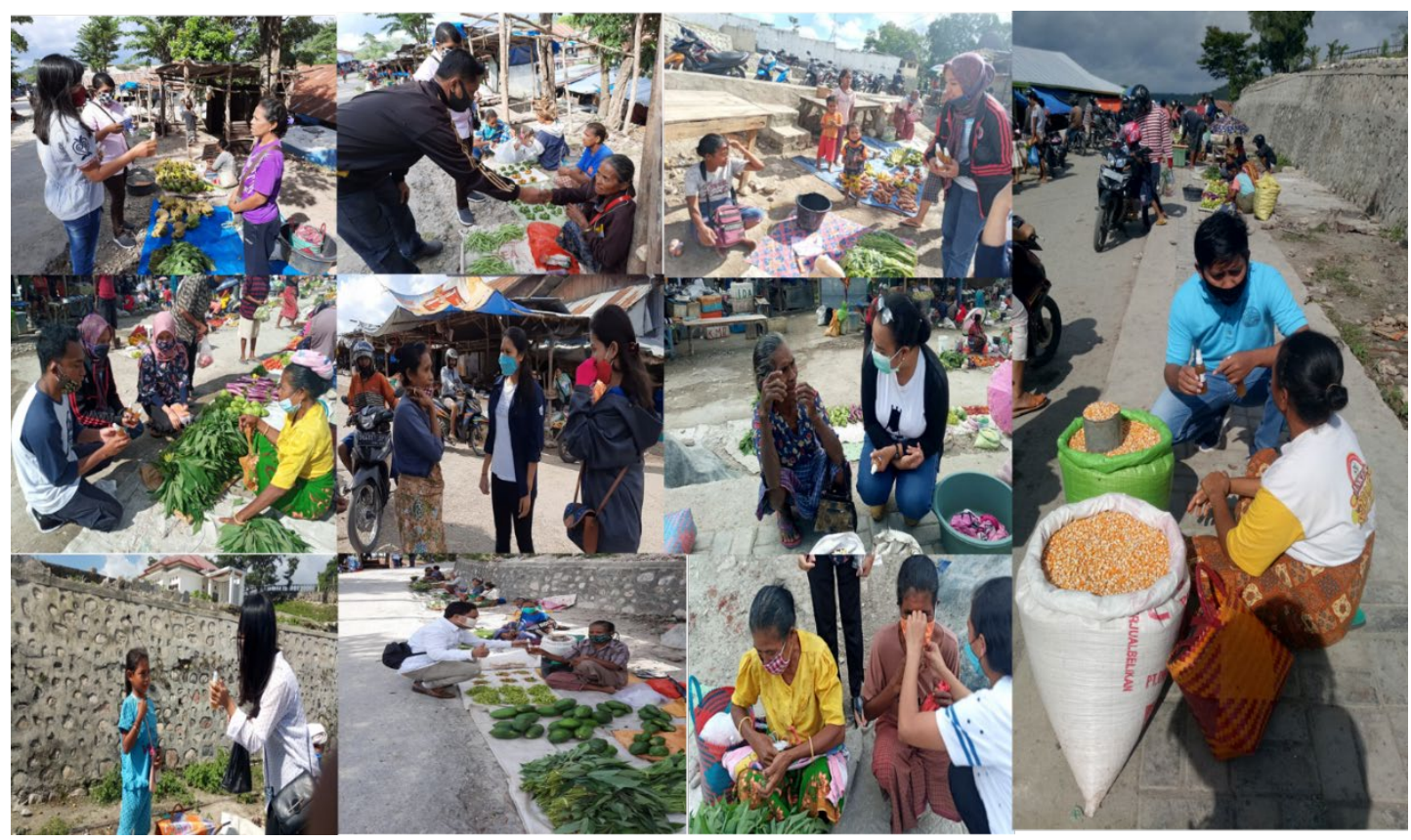

Gambar 3.2. Proses Edukasi dan Pembagian Hand sanitizer Daun Sirih kepada Pedagang Pasar Baru Kefamenanu

Secara keseluruhan pedagang memberikan respon yang baik terhadap kegiatan ini. Namun, masih banyak pedagang yang belum mengetahui tentang fungsi dan cara menggunakan hand sanitizer. Oleh karena itu, perlu lebih banyak sosialisasi mengenai bagaimana menjaga kebersihan dengan menggunakan hand sanitizer setelah melakukan transaksi jual beli untuk menghindari terjangkit virus korona. Dengan adanya kegiatan ini sangat membantu pedagang untuk mengetahui cara membuat dan menggunakan hand sanitizer.

\section{KESIMPULAN}

Berdasarkan hasil dan pembahasan dapat disimpulkan bahwa:

a. Pedagang di Pasar Baru Kefamenanu memperoleh informasi tentang cara membuat hand sanitizer sendiri dari bahan alami.

b. Hand sanitizer yang dibagikan dapat digunakan oleh pedagang untuk menjaga kebersihan tangan.

\section{UCAPAN TERIMAKASIH}

Terimakasi kepada pihak Fakultas Pertanian dan Lembaga Penelitian dan Pengabdian kepada Masyarakat (LPPM) Universitas Timor yang telah mendukung kami selama proses persiapan hingga pelaksanaan pengabdian. 


\section{DAFTAR PUSTAKA}

Kursia, S., Lebang, J. S., Taebe, B., Burhan, A., \& Wa, O. R. (2016). Uji Aktivitas Antibakteri Ekstrak Etilasetat Daun Sirih Hijau (Piper betle L .) terhadap Bakteri Staphylococcus epidermidis. IJPST, 3(2), 72-77.

Opilia, T., Priyantono, \& Suharyani, I. (2016). Formulasi Minyak Atsiri Daun Sirih Hijau (Piper bettle L .) dalam Sediaan Gel Pencuci Tangan. Farmaku, 1(1), 25-32.

Sari, R., \& Isadiartuti, D. (2006). Studi Efektivitas Sediaan Gel Antiseptik Tangan Ekstrak Daun Sirih (Piper betle Linn.). Majalah Farmasi Indonesia, 17(4), 163-169.

Widyaningtias, N. M. S. R., Yustiantara, P. S., \& Paramita, N. L. P. V. (2014). Uji Aktivitas Antibakteri Ekstrak Terpurifikasi Daun Sirih Hijau (Piper betle L.) terhadap Bakteri Propionibacterium acnes. Farmasi Udayana, 3(1), 50-53. 